\section{Deeper than DNA}

\section{RATIONALIZING Epidemics \\ Rationalizing Epidemics: Meanings and Uses of American Indian Mortality since 1600}

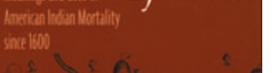

\author{
by David S. Jones
}

Harvard University Press, 2004

308 pp., hardcover, $\$ 49.95$

ISBN 0674013050

\section{Reviewed by Morris W Foster}

Rationalizing Epidemics provides the opportunity to rethink contemporary views of health disparities and examine the motivations behind efforts to address them. David Jones does this through four case studies of epidemics in the American Indian population from 1600 to the 1960s. In each case he examines European and Euro-American reactions to these epidemics, ranging from sincere attempts to take responsibility for Native American mortality and provide aid to more cynical attempts to use the disparity to seize land, impose cultural and religious assimilation, and conduct research studies. These studies are rich in historical depth and detail, and admirably documented using both primary and secondary sources.

From 1492 to the early twentieth century, American Indian populations experienced $90 \%$ to $95 \%$ mortality, largely as a result of their contact with Europeans. In contrast, after 1900, those same populations experienced an expansion such that, in some estimates, more Native American people - are alive today than at any time since their initial arrival in North America. That remarkable history of population contraction and expansion often is attributed by historians to, in the first place, a lack of immunity to diseases such as smallpox that had afflicted Europeans for generations and, in the second place, to the subsequent increasing availability of Western medicine and lifestyles.

As Jones points out, though, this simplistic historical rationalization ignores the fact that many European colonists died of the very same epidemics that afflicted the indigenous populations. Similarly, American Indians today still have higher incidences of chronic diseases such as diabetes and shorter average life spans, despite access to hospitals and Wal-Marts. Those observations make clear that disparities in mortality are not just the result of biological mechanisms such as higher frequencies of disease-susceptibility genes and that reductions in those disparities do not necessarily follow from improvements in medical knowledge and technology.

The missing factor identified by Jones is a disparity in economic and political power between populations. European colonists in the seventeenth century did not just introduce infectious diseases to Native American

Morris W. Foster is in the Department of Anthropology, University of Oklahoma, Norman, Oklahoma 73019, USA.

e-mail: morris.w.foster-1@ou.edu populations; the colonists also disrupted the political organizations that coordinated care within Native American communities, and the traditional subsistence activities and economic networks that provided sufficient food and other resources to survive the aftermath of epidemics. For the most part, European political and economic systems were not disrupted, so more Europeans than Native Americans survived the epidemics.

By the nineteenth century, the economic and political disparities between Euro-Americans and Native Americans had grown exponentially. Native Americans were forcibly relegated to less desirable geographic enclaves (many of which were later taken away as Euro-American technologies made previously unusable locations more attractive for exploitation). This displacement occurred under conditions that sharply limited Native American economic opportunities. Consequently, American Indian experiences of diseases such as tuberculosis were much more catastrophic than those of Euro-Americans.

Jones argues that such heightening of Native American mortality for reasons beyond biology increasingly made twentieth-century Native American communities objects of study for diseases also affecting European-Americans. Similar health disparities made eighteenth- and nineteenth-century Native American communities the targets of Christian conversion. Scientists often choose to study diseases in communities in which they are more frequent. But the paradox in the American Indian case is that common diseases among Native American people have been investigated largely as biological phenomena although their greater frequencies result primarily from non-biological causes. Jones suggests that American Indian health disparities, as in the case of health disparities in other disadvantaged populations, can be resolved by equalizing economic opportunities with the Euro-American population—not by discovering biological pathways and mechanisms for disease expression.

Although Jones does not use it as one of his case studies because it is not a communicable disease, the 'epidemic' of type 2 diabetes among American Indians is a case in point. Although large amounts of research funding have been spent on genetic, epidemiologic and other biomedical studies of diabetes in American Indians, the incidence and mortality of the disease have continued to grow in Native American populations. That continued increase has only heightened the investment in research projects and infrastructure for studying a disease that was largely nonexistent among Native American people prior to the mid-twentieth century. Jones' analysis of other historical examples suggests that the American Indian epidemic of diabetes can be explained primarily by Native American economic disparities and that the beneficiaries of biomedical research on diabetes among American Indians are the researchers and their institutions and not Native American people.

At a time in which the relationship between race and genetics is much debated, I find Rationalizing Epidemics to be a valuable, well-researched example of how historical conditions_-and not biology_-have been mainly responsible for perceptions of health disparities in a racially defined population. Seen from a purely epidemiologic perspective, being American Indian would appear to be an inherent risk factor for disease and early mortality. Seen in the historical context, however, the heightened disease incidence and mortality that American Indians have experienced over the last five centuries is the result of their interactions with Europeans and Euro-Americans, and not of their ancestry. 